\title{
Sosialisasi dan Pendampingan Manajemen Konflik dalam Rumah Tangga Isteri yang Bekerja di Perum Citra Permata Sakinah Purwakarta
}

\author{
Sofia Gussevi \\ Program studi Ahwal al-Syakhsiyyah, STAI DR. KH. EZ. Muttaqien Purwakarta \\ e-mail: sofiagussevi@staimuttaqien.ac.id
}

DOI: https://doi.org/10.52593/svs.01.1.01 Naskah diterima: 25 Maret 2020, direvisi: 02 November 2020, disetujui: 14 Januari 2021

\section{Abstraksi}

Kata Kunci:

Konflik, Manajemen,

Istri, Bekerja

\begin{abstract}
Kegiatan pengabdian ini dilatarbelakangi dari data Pengadilan Agama kabupaten Purwakarta tekait tingginya kasus gugatan cerai yang dilakukan isteri kepada suaminya, dan hal ini terjadi mayoritas pada isteri yang bekerja di luar rumah baik itu di kantor pemerintaham, swasta atau pabrik. Berdasarkan hal tersebut, kegiatan ini bertujuan untuk memberikan sosialisasi tentang manajemen konflik dalam keluarga dengan melakukan pendampingan terhadap beberapa keluarga di Perum Citra Permata Sakinah, Purwakarta. Hasil dari kegiatan ini diperoleh bahwa telah terjadi disharmonisasi keluarga berupa berkurangnya komunikasi pasangan yang diakibatkan perbedaan pandangan, faktor ekonomi, dan kecemburuan sosial. Adapun upaya yang telah dilakukan dalam kegiatan ini adalah berupa musyawarah antar pasangan dengan melibatkan pihak ketiga dalam hal ini adalah orangtua.
\end{abstract}

\section{PENDAHULUAN}

Dalam menjalini kehidupan perkawinan sebagai suami isteri, membentuk keluarga yang bahagia dan kekal jelas tidak segampang yang dibayangkan. Keluarga bahagia bukan berarti keluarga yang diam tanpa masalah, namun lebih kepada adanya keterampilan mengelola konflik yang terjadi di dalamnya.

Konflik merupakan masalah yang dapat menyebabkan pertengkaran, perselisihan, atau benturan di antara kedua belah pihak. Jika konflik tidak diatasi sedini mungkin dengan disertai solusi yang baik, maka akan menimbulkan masalah yang jauh lebih buruk dari sebelumnya. Terjadinya konflik dalam rumah tangga merupakan suatu hal yang wajar, dan setiap pasangan suami isteri harus memahami dan mengerti faktor penyebab dari konflik tersebut.

Sumber konflik perkawinan dapat berasal dari status isteri yang bekerja. Misalnya ketika pekerjaan di luar rumah dianggap isteri sebagai hal penting bagi perkembangan potensinya, sedangkan suami menganggap bahwa kedekatan suami isteri akan berkurang dan pengasuhan anak akan terabaikan apabila isteri bekerja di luar rumah. Demikian juga terjadi angka perceraian meningkat disebabkan oleh pertentangan antara suami dan isteri yang keduanya sama-sama bekerja.

Mengenai perceraian ini, gugatan cerai isteri kepada suaminya mendominasi kasus perceraian di Kabupaten Purwakarta, Jawa Barat. Faktor ekonomi disebut-sebut menjadi penyebab utama kaum hawa lebih memilih tidak ingin berlama-lama mengarungi bahtera rumah tangganya. Hal ini terungkap berdasarkan data yang ada di Kantor Pengadilan Agama Purwakarta. Sepanjang tahun 2015 laporan perkara di Pengadilan Agama Purwakarta mengenai cerai gugat mencapai 895 perkara, sedangkan perkara cerai gugat yang diputus 
sebanyak 844 perkara. Jumlah cerai gugat ini berbanding terbalik dengan jumlah cerai talak, sepanjang tahun 2015 Pengadilan Agama Purwakarta menerima 334 perkara dan perkara yang diputus sebanyak 285 perkara $^{1}$.

Penyebab utama kasus cerai gugat dilakukan para isteri didominasi masalah ekonomi. Kemudian selingkuh dan terjadinya Kekerasan Dalam Rumah Tangga (KDRT). "Artinya dari data yang ada memang kasus cerai gugat masih menempati urutan pertama. Disusul di urutan kedua kasus cerai talak yang diajukan suami. Meski demikian, angka perceraian di Purwakarta masih rendah dibanding Subang, Karawang dan Indramayu," ujar Hj. N. Kesih, S. Ag. bidang Panitera Muda Hukum di Pengadilan Agama Purwakarta².

"Analisa saya, alasannya ekonomi. Penghasilan isteri lebih besar dari suaminya. Atau isteri bekerja sedangkan suaminya menganggur," urai Ruhiat yang juga kerap menjadi kuasa hukum ibu rumah tangga menggugat cerai suaminya. Dia menambahkan, "kelompok pemohon cerai gugat dan cerai talak berasal dari kalangan masyarakat umum dan buruh pabrik, mereka rata-rata yang usia perkawinan muda atau yang berumah tangga di bawah 10-5 tahun" jelasnya ${ }^{3}$.

Dari data serta hasil wawancara yang penulis lakukan di Pengadilan Agama Purwakarta tersebut menunjukkan bahwa rumah tangga yang isteri bekerja sebagai buruh atau karyawan pabrik yang banyak mengajukan cerai gugat. Pada tahun 2018 ketika penulis menjadi pembimbing mahasiswa Praktek Profesi Lapangan (PPL) lagi di Pengadilan Agama Purwakarta, penulis juga menemukan permasalahan yang sama yaitu rumah tangga yang isteri bekerja sebagai buruh atau karyawan pabrik banyak mengajukan cerai gugat.

Berkaitan dengan hal di atas, isteri yang bekerja inilah yang menjadi fokus penulis dalam penelitian ini. Penulis telah melakukan observasi awal di Perum Citra Permata Sakinah RT 014 RW 006 Desa Babakancikao Kecamatan Babakancikao Kabupaten Purwakarta. Perum Citra Permata Sakinah RT 014 RW 006 Desa Babakancikao ini terdiri dari 77 Kepala Keluarga (KK), hampir 75\% isteri bekerja. Ada yang bekerja sebagai karyawan pabrik, bekerja di lembaga pemerintahan, buka warung di rumah, onlineshop dan lain sebagainya. Tetapi isteri bekerja yang dimaksud dalam tulisan ini adalah isteri yang memang bekerja di luar rumah dan terikat dengan waktu tertentu. Dari 77 Kepala Keluarga (KK) itu ada 30\% (23 orang) isteri bekerja di lembaga pemerintahan (ruang publik) dan lembaga swasta serta bekerja sebagai buruh atau karyawan di pabrik.

Bekerja di lembaga pemerintahan dan lembaga swasta terikat dengan waktu yang sudah ditentukan. Apalagi yang bekerja di pabrik yang jam kerjanya pun dikenai 3 shift (pagi, siang, dan malam), serta dengan jadwal libur yang bergantian dengan karyawan lain. Hal ini akan berimbas kepada keluarga mereka.

Melihat dari sisi wilayah, Purwakarta sendiri telah menjadi tempat industri yang baik, terbukti dengan adanya berbagai jenis pabrik yang memproduksi mulai dari jenis makanan, kemasan makanan, otomotif, elektronik, tekstil, sampai garment. Pabrik garment sangat di dominasi oleh kaum perempuan, tapi pabrik otomotif dan elektro biasanya lebih banyak memperkerjakan kaum laki-laki.

Banyak alasan yang menyebabkan seorang isteri memutuskan untuk bekerja, salah satunya karena ingin membantu ekonomi keluarga. Isteri merasa keluarganya perlu

\footnotetext{
${ }^{1}$ N. Kesih, Panitera Muda Hukum PA Purwakarta, Wawancara Mendalam, Purwakarta, 3 Mei 2016 ${ }^{2}$ Ibid.

${ }^{3}$ Ruhiat, Praktisi Hukum di PA Purwakarta, Wawancara Mendalam, Purwakarta, 3 Mei 2016
} 
memperoleh income dari kedua belah pihak, sehingga isteri ambil bagian dalam segi ekonomi keluarga. Selain itu sebenarnya keinginan untuk mengaktualisasikan diri karena pendidikannya yang cukup tinggi juga menjadi alasan lain seorang isteri memutuskan bekerja.

Apabila dilihat dalam kenyataan yang terjadi di masyarakat, sebenarnya tidak semua isteri yang bekerja di luar rumah itu menjadi suatu masalah dan menjadi sumber konflik, sehingga berakhir dengan perceraian. Ada juga isteri sibuk bekerja di luar rumah, tetapi rumah tangganya tetap aman dan bahagia saja.

Dari uraian di atas dapat diidentifikasikan masalah sebagai berikut : 1) Tujuan perkawinan adalah membentuk keluarga yang bahagia dan kekal; 2) Dalam menjalani rumah tangga, pasangan suami isteri akan menemui berbagai konflik yang terjadi; 3) Konflik dalam rumah tangga ini lebih mungkin terjadi apabila isteri bekerja, apalagi bekerja di pabrik; 4) Konflik dalam rumah tangga akan menimbulkan berbagai dampak; 5) Setiap pasangan suami isteri diharapkan sebisa mungkin menghindari terjadinya perceraian.

Tujuan penelitian masalah dalam penelitian ini adalah sebagai berikut : 1) Untuk mengetahui ragam konflik yang terjadi dalam rumah tangga isteri yang bekerja Perum Citra Permata Sakinah?; 2) Bagaimana upaya manajemen konflik yang diterapkan dalam rumah tangga isteri yang bekerja Perum Citra Permata Sakinah?.

Dengan demikian penelitian ini diharapkan bisa berguna untuk memahami, mengembangkan dan menemukan teori baru serta menjadi rujukan dalam melakukan penelitian selanjutnya terutama mengenai manajemen konflik dalam rumah tangga. Terutama sebagai rujukan keilmuan bagi para akademisi, peneliti, mahasiswa melalui mata kuliah Hukum Perdata Islam di Indonesia dan Peradilan Agama di Indonesia.

\section{METODE}

Metode kegiatan ini menggunakan Participatory Research, di mana peneliti terlibat langsung dala proses sosialisasi dan pendampingan kepada keluarga yang ada di Perum Citra Permata Sakinah, Purwakarta, baik terhadap istri, suam dan orang-orang yang dianggap sebagai pihak yang turut mempengaruhi terhadap berbagai kasus perceraian tersebut.

\section{HASIL DAN PEMBAHASAN}

\section{A. Hasil Kegiatan}

Dalam kegatan pengabdian kepada masyarakat ini diperoleh data bahwa bentuk konflik dalam rumah tangga isteri yang bekerja Perum Citra Permata Sakinah, ${ }^{4}$ antara lain :

1) Perdebatan/Pertengkaran,

Perdebatan hingga terjadi percekcokan merupakan salah satu bentuk konflik yang terjadi dalam rumah tangga. Biasanya ini terjadi karena tingkat emosi yang sama-sama meningkat, tidak ada yang mau mengalah dan beranggapan bahwa dirinyalah yang paling benar serta sama-sama ingin menang sendiri.

2) Tidak saling tegur sapa dengan pasangan

Tidak saling tegur sapa dengan pasangan bisa terjadi karena kesalahan yang sudah beberapa kali dilakukan oleh pasangan dan berkali-kali pula pasangannya memaafkan. Sikap tidak menghargai keputusan pasangan dan terlalu mementingkan urusannya sendiri, semuanya itu sebagai pemicu konflik yang bentuk konfliknya tidak bertegur sapa dengan pasangannya yang akan membuat rumah tangga semakin tegang.

\footnotetext{
${ }^{4}$ Isteri yang bekerja Perum Citra Permata Sakinah, Wawancara Mendalam, Purwakarta September-
} Oktober 2019 
Adapun penyebab terjadinya konflik dalam rumah tangga isteri yang bekerja Perum Citra Permata Sakinah, ${ }^{5}$ antara lain :

1) Perbedaan pendapat/argument

Perbedaan pendapat ini biasanya terjadi karena persepsi yang berbeda dalam melihat masalah. (Effendi, 2020a)Hal ini dipengaruhi oleh latar belakang pendidikan, kepribadian dan juga pengalaman yang mereka alami selama ini, serta pola asuh keluarga dari masing-masing pasangan. Perbedaan pendapat yang sering terjadi dalam rumah tangga adalah mengenai anak.

2) Kecemburuan pasangan

Sifat cemburu dapat lahir dari sikap tidak percaya diri, adanya kekhawatiran dan ketakutan yang berlebihan terhadap pasangan suami atau isteri yang akan tidak setia atau berpindah ke lain hati. Ketidakpercayaan ini akan menimbulkan permasalahan dalam rumah tangga.

3) Keadaan ekonomi rumah tangga

Uang bisa menyebabkan terjadinya konflik dalam keluarga. Terlalu sedikit uang, hampir dan selalu menimbulkan krisis dalam rumah tangga. Terlalu banyak uangpun menyebabkan gangguan fisik dan non fisik, seperti susah tidur dan lainnya. Untuk menghindari konflik mengenai ekonomi keluarga maka perlu adanya sikap saling percaya dan jujur antara suami dan isteri.

Selain itu, faktor eksternal, di antaranya :

a) Hadirnya pihak ketiga

Pihak ketiga dalam hal ini bukan hanya dalam arti "selingkuh" tetapi juga orang yang berniat dan berusaha mengganggu keutuhan rumah tangga.

b) Orang tua

Tindakan orang tua dapat menimbulkan masalah dalam rumah tangga anaknya, misalnya orang tua yang over protektif dan orang tua yang biasa memanjakan anaknya. Menghadapi orang tua yang seperti itu perlu diberikan pemahaman atau dengan cara setelah menikah tidak tinggal bersama orang tua, baik dengan orang tua suami ataupun orang tua isteri.

c) Lingkungan

Lingkungan merupakan bagian yang terpenting dan mendasar dari kehidupan manusia. Lingkungan sangat besar pengaruhnya terhadap perilaku seseorang, begitupun dengan kehidupan rumah tangga. Pasangan yang baru memulai kehidupan menjadi sepasang suami isteri tentunya harus bisa beradaptasi dengan lingkungan barunya.

Adapun dampak konflik dalam rumah tangga isteri yang bekerja Perum Citra Permata Sakinah ${ }^{6}$ anatara lain :

1. Dampak positif terjadinya konflik dalam rumah tangga di antaranya :

a) Memandang bahwa konflik merupakan nikmat dari Allah SWT., berprasangka baik terhadap takdir-Nya.

b) Penyesuaian diri dengan lingkungan rumah tangga.

c) Lebih berhati-hati dalam bertindak di kemudian hari. 
d) Sebagai langkah intropeksi diri dalam rumah tangga.

2. Dampak negatif terjadinya konflik dalam rumah tangga di antaranya : :

a) Terhambatnya komunikasi antar pihak yang berkonflik.

b) Terganggunya kerjasama dalam rumah tangga.

c) Timbulnya rasa ketidakpuasan dalam berumah tangga.

Manajemen konflik yang dilakukan dalam rumah tangga isteri yang bekerja Perum Citra Permata Sakinah(Effendi, 2020b), ${ }^{7}$ jika terjadi konflik dalam rumah tangga isteri yang bekerja Perum Citra Permata Sakinah, maka yang mereka melakukan :

1. Mencari hal yang melatarbelakangi konflik tersebut;

2. Bermusyawarah mencari solusi baik dengan pasangan maupun melibatkan pihak ketiga biasanya orang tua;

3. Berdiam diri mengintropeksi kesalahan sendiri yang mengakibatkan konflik tersebut muncul;

4. Saling memahami dan saling pengertian terhadap perbedaan dan kebiasaan dari masing-masing pasangan.

\section{B. Pembahasan}

Perdebatan hingga terjadi percekcokan biasanya ini terjadi karena tingkat emosi yang sama-sama meningkat, dan tidak ada yang mau mengalah, serta beranggapan bahwa dirinyalah yang paling benar. Ketika keduanya cekcok adu mulut, mereka tidak sadar bahwa mereka berbicara dalam keadaan marah dan tidak akan bertemu dengan pemecahan masalah yang sedang dihadapi, justru akan menambah ketegangan di antara keduanya. Sebaiknya masing-masing pasangan sadar, ketika suaminya sedang emosi, lebih baik isteri jangan memancing hal-hal yang akan membuat suasana lebih kacau. Setelah suami selesai berbicara maka giliran isteri untuk berbicara.

Selanjutnya tidak saling tegur sapa dengan pasangan biasanya disebabkan rasa kecewa yang sangat mendalam. Saling diam ini mengakibatkan terhambatnya komunikasi antar pihak yang berkonflik. Rumah tangga yang baik adalah yang melakukan komunikasi dengan baik terhadap pasangannya. Tidak saling tegur sapa dengan pasangan ini juga akan mengganggu kerjasama dalam rumah tangga, maka sulit rasanya rumah tangga tersebut dapat berhasil mencapai tujuannya.

\section{Penyebab Terjadinya Konflik dalam Rumah Tangga Isteri yang Bekerja Perum Citra Permata Sakinah}

Mengenai penyebab terjadinya konflik diuraikan A. Rusdiana dalam bukunya Manajemen Konflik ${ }^{8}$, walaupun sebenarnya buku A. Rusdiana tersebut mengenai manajemen konflik dalam organisasi, hal ini juga dapat terlihat pada faktor terjadinya konflik dalam rumah tangga secara umum atau rumah tangga suami dan isteri yang sama-sama bekerja.

Konflik yang terjadi dalam rumah tangga, mulai dari menyatukan visi dan misi, beradaptasi dengan lingkungan pasangan, beradaptasi dengan keluarga pasangan dan beradaptasi dengan kebiasaan-kebiasaan pasangan dari sebelum menikah yang terbawa sampai setelah menikah. Apalagi konflik itu terjadi dalam rumah tangga isteri yang bekerja, maka hal itu juga dapat memperparah keadaan. Hal ini dikarenakan sebagian besar waktu

${ }^{7}$ Ibid.

${ }^{8}$ Rusdiana, Manajemen Konflik, 151 
isteri yang bekerja ini digunakan untuk berkerja, dan waktu untuk melaksanakan kewajibannya sebagai isteri dan ibu dalam rumah tangga menjadi berkurang.

Perbedaan yang terjadi dalam rumah tangga tidak bisa dihindari. Perlu waktu untuk menyadari dan menyikapi perbedaan itu. Sering kali kita mendengar seseorang mengakhiri pernikahannya dengan alasan "sudah tidak ada kecocokan lagi". Kata-kata ini jugalah yang sering diucapkan oleh seorang perempuan di depan pengadilan mengenai alasannya menggugat cerai suaminya ${ }^{9}$. Sebaiknya perbedaan bukan alasan seseorang harus mengakhiri rumah tangganya namun lebih kepada suami dan isteri mencari solusi terhadap konflik yang terjadi tersebut dan membuat manajemen yang baik dalam rumah tangganya, sehingga konflik yang muncul tidak mengakibatkan perceraian. Kalau dilihat konflik yang terjadi dalam rumah tangga isteri yang bekerja ini, yang sering terjadi adalah mengenai pengasuhan anak. Karena kesibukan pekerjaan isteri sekaligus ibu yang bekerja, seringkali kewajibannya terhadap anak terabaikan. Sebenarnya tidak ada salahnya juga minta bantuan kepada keluarga terdekat dalam pengasuhan anak ini, misalnya kepada orang tua atau saudara perempuan dari suami maupun isteri. Tetapi harus disadari juga, walaupun orang tua mau membantu dalam pengasuhan anak, pada dasarnya orang tua juga merasa lelah kalau pengasuhan anak ini diserahkan sepenuhnya kepada mereka ${ }^{10}$.

Ketika seorang perempuan yang telah berumah tangga dan telah memiliki anak, kemudian memutuskan untuk bekerja maka dirinya harus mampu menjalankan peran ganda, baik peran sebagai isteri maupun peran sebagai ibu. Kalau isteri yang bekerja itu merasa tidak mampu menjalankan peran ganda tersebut, maka lebih baik mundur dari pekerjaan dan lebih mengutamakan pengasuhan anak ${ }^{11}$. Karena keluarga adalah sekolah pertama bagi seorang anak dan ibu adalah guru yang utama yang akan mengajari norma-norma kepada anak untuk bersikap dan bertingkah laku dengan baik.

Berkaitan dengan isteri yang bekerja, kalau dilihat dari perspektif hukum Islam, sebenarnya tidak ada larangan kepada isteri untuk bekerja di luar rumah. Tetapi yang harus menjadi dasar dan yang harus disadari oleh isteri yang bekerja itu adalah kewajibannya sebagai isteri dan kewajibannya sebagai ibu tidak terabaikan disebabkan kesibukannya dalam bekerja, karena itu merupakan tugas dan fungsi yang utama isteri dalam rumah tangga.

\section{Dampak Konflik dalam Rumah Tangga Isteri yang Bekerja Perum Citra Permata Sakinah}

Berdasarkan hasil penelitian terlihat bahwa konflik yang terjadi dalam rumah tangga isteri yang bekerja Perum Citra Permata Sakinah selain mendatangkan dampak negatif, sebenarnya juga dapat mendatangkan dampak positif.

Dengan demikian, walaupun banyak terjadi konflik dalam rumah tangga isteri yang bekerja, hendaknya jangan bersikap pesimis tetapi harus optimis dalam menjalani kehidupan,

\footnotetext{
${ }^{9} \mathrm{Hal}$ ini penulis temukan pada waktu membimbing mahasiswa dalam pelaksanaan Praktek Profesi Lapangan di Pengadilan Agama Purwakarta. Dalam persidangan, ketika hakim menanyakan alasan kepada perempuan yang mengajukan gugat cerai, sering kali mengungkapkan dengan kalimat "sudah tidak cocok lagi Pak".

${ }^{10}$ Nenek Ica, Mertua Ira (Isteri yang Bekerja Perum Citra Permata Sakinah) Wawancara Mendalam, Purwakarta 20 Oktober 2019. Nenek Ica inilah yang mengasuh anak Ira ketika Ira dan suaminya berkerja.

${ }^{11}$ Mila dan Endah, Isteri yang Bekerja Perum Citra Permata Sakinah, Wawancara Mendalam, Purwakarta 22 September 2019. Pada waktu diwawancara mereka sudah berhenti bekerja.
} 
harus berusaha mencari solusi yang terbaik secara bersama-sama dengan pasangan. Jangan menyerah dengan keadaan, apalagi sampai memutuskan dengan jalan perceraian. Kalaupun terjadi konflik dalam rumah tangga, tetap memandang bahwa konflik merupakan nikmat dari Allah SWT. dan berprasangka baik terhadap takdir Allah. Pada setiap masalah pasti ada jalan keluarnya. Allah tidak sertamerta mempertemukan kita dengan pasangan kita kalau tidak ada takdir baik dari Allah untuk kita.

\section{Manajemen Konflik dalam Rumah Tangga Isteri yang Bekerja Perum Citra Permata Sakinah}

Dalam membina rumah tangga, manajemen konflik dibutuhkan untuk meminimalisir konflik yang terjadi, dimulai dari menyadari akan hak dan kewajiban sebagai suami isteri serta cerdas membaca situasi rumah tangga. Apabila terjadi konflik, suami atau isteri harus membicarakannya dengan pasangannya terlebih dahulu, baru kemudian melibatkan keluarga yaitu orang tua atau mertua, maupun saudara. Ataupun dapat juga dengan meminta pendapat kepada orang yang dipercaya dapat menyelesaikan masalah yang mereka hadapi. Hal ini sebagaimana terdapat dalam firman Allah yang berbunyi :

Artinya : Dan jika kamu khawatirkan ada persengketaan antara keduanya, Maka kirimlah seorang hakam (pendamai) dari keluarga laki-laki dan seorang hakam dari keluarga perempuan. jika kedua orang hakam itu bermaksud mengadakan perbaikan, niscaya Allah memberi taufik kepada suami-isteri itu. Sesungguhnya Allah Maha mengetahui lagi Maha Mengenal. ${ }^{12}$

Sebagaimana yang terdapat dalam firman Allah yang berbunyi :

Artinya : Dan di antara tanda-tanda kekuasaan-Nya ialah Dia menciptakan untukmu isteri-isteri dari jenismu sendiri, supaya kamu cenderung dan merasa tenteram kepadanya, dan dijadikan-Nya di antaramu rasa kasih dan sayang. Sesungguhnya pada yang demikian itu benar-benar terdapat tanda-tanda bagi kaum yang berfikir. ${ }^{13}$

Dalam ayat di atas "...dan dijadikan di antara keduanya kasih dan sayang..." menunjukkan bahwa yang sangat dibutuhkan oleh suami dan isteri dalam rumah tangga adalah rasa saling mengasihi, menyayangi, mencintai, mengayomi, bekerja sama, sabar, bersikap lemah lembut, memahami serta mendahulukan kepentingan bersama dan tidak selalu menuntut hak.

Sedangkan gaya manajemen konflik seperti yang diungkapkan oleh Winardi J. dalam bukunya Motivasi dan Pemotivasian ${ }^{14}$, ada beberapa gaya manajemen konflik yaitu : Tindakan Menghindari (Avoiding), Kompetisi atau Komando Otoratif, Akomodasi dan Meratakan, Kompromis serta Kolaborasi (kerja sama) atau Pemecahan Masalah. Berdasarkan gaya manajemen konflik yang dipaparkan oleh Winardi J. tersebut, maka gaya manajemen konflik yang digunakan oleh isteri yang bekerja Perum Citra Permata Sakinah adalah gaya kolaborasi yaitu berupaya mencapai kepuasan setiap pihak yang berkepentingan, mencari dan memecahkan masalah sehingga setiap orang mencapai keuntungan sebagai hasilnya. Hal ini berarti isteri yang bekerja tersebut bersama-sama dengan suaminya menyelesaikan konflik

\footnotetext{
${ }^{12}$ QS. al-Nisaa' (4) : 35

${ }^{13} \mathrm{QS}$. al-Ruum (30) : 21

14 Winardi J., Motivasi dan Pemotivasian, 26
} 
yang terjadi dalam rumah tangga mereka. Dalam menanggulangi konflik yang terjadi, isteri yang bekerja tersebut bersama suaminya melakukan pengelolaan konflik secara efektif.

Berkaitan dengan semakin meningkatnya angka cerai gugat yang terjadi di Pengadilan Agama Purwakarta, penulis menyimpulkan hal itu disebabkan karena suami atau isteri masih mempertahankan egonya masing-masing. Bisa juga disebabkan isteri yang bekerja yang mengajukan cerai gugat tersebut terbilang rata-rata yang usia perkawinan muda dan atau yang berumah tangga di bawah 10-5 tahun ${ }^{15}$. Sehingga manajemen konflik yang diterapkan belum maksimal dilaksanakan. Selain hal itu, cerai gugat ini juga disebabkan karena sekarang ini semakin tinggi tingkat pendidikan perempuan ${ }^{16}$.

Dengan demikian dapat dikatakan meningkatnya angka cerai gugat yang terjadi di Pengadilan Agama Purwakarta disebabkan manajemen konflik yang belum maksimal dilaksanakan masing-masing pasangan suami isteri, karena usia perkawinan muda dan atau yang belum lama berumah tangga. Alasan lainnya yaitu semakin tingginya tingkat pendidikan perempuan sekarang ini.

\section{KESIMPULAN}

Berdasarkan uraian sebelumnya, maka dapat diambil kesimpulan sebagai berikut :

1. Konflik yang terjadi dalam rumah tangga isteri yang bekerja Perum Citra Permata Sakinah berupa perdebatan/pertengkaran dan tidak saling tegur sapa dengan pasangan. Dan konflik tersebut disebabkan oleh banyak hal, di antaranya perbedaan pendapat, kecemburuan pasangan, keadaan ekonomi rumah tangga serta faktor eksternal : pihak ketiga, orang tua serta lingkungan sekitar yang membentuk karakter pasangan tersebut. Selanjutnya konflik yang terjadi dalam rumah tangga tersebut dapat mendatangkan dampak negatif antara lain terhambatnya komunikasi antar pihak yang berkonflik, terganggunya kerjasama dalam rumah tangga serta timbulnya rasa ketidakpuasan dalam berumah tangga. Selain mendatangkan dampak negatif, sebenarnya konflik dalam rumah tangga tersebut dapat berdampak positif juga di antaranya memandang bahwa konflik merupakan nikmat dari Allah SWT., penyesuaian diri dengan lingkungan rumah tangga, membuat rumah tangga lebih harmonis, lebih berhati-hati dalam bertindak di kemudian hari, serta sebagai langkah intropeksi diri dalam rumah tangga.

2. Manajemen konflik yang diterapkan isteri yang bekerja Perum Citra Permata Sakinah dalam rumah tangga mereka yaitu dengan cara pendekatan terhadap hal yang melatarbelakangi konflik tersebut, mereka bermusyawarah mencari solusi baik dengan pasangan maupun melibatkan pihak ketiga biasanya orang tua, berdiam diri mengintropeksi kesalahan sendiri yang mengakibatkan konflik tersebut muncul, serta saling memahami dan saling pengertian terhadap kebiasaan dari masing-masing pasangan. Dengan demikian, gaya manajemen konflik yang diterapkan yaitu gaya kolaborasi. Isteri yang bekerja tersebut bersama-sama dengan suaminya menyelesaikan konflik yang terjadi dalam rumah tangga mereka sehingga keinginan mereka tercapai.

\footnotetext{
${ }^{15} \mathrm{Hal}$ ini penulis dapatkan ketika wawancara dengan Praktisi Hukum di Pengadilan Agama Purwakarta sebagaimana telah penulis jelaskan dalam BAB sebelumnya.

${ }^{16 N u r d i n}$ (Hakim Pengadilan Agama Purwakarta), hal ini disampaikan dalam pemaparan materi yang diadakan di Ruang Sidang Utama Pengadilan Agama Purwakarta dalam acara Praktek Profesi Lapangan mahasiswa Prodi Ahwal al-Syakhsiyyah STAI DR. KHEZ. Muttaqien di Pengadilan Agama Purwakarta.
} 


\section{DAFTAR PUSTAKA}

Arikunto, Suharsimi, 2006. Prosedur Penelitian Suatu Pendekatan Praktek, Jakarta : Rineka Cipta

Bedjo, Siswanto, 1990. Organisasi Kepemimpinan dan Perilaku Administrasi, Jakarta : Haji Masagung

Effendi, M. R. (2020a). Mitigasi Intoleransi dan Radikalisme Beragama di Pondok Pesantren Melalui Pendekatan Pembelajaran Inklusif. Paedagogie, I(I), 55-74. https://doi.org/doi.org/10.20211/pdg.01.1.05

Effendi, M. R. (2020b). Pertalian Agama dalam Pilkada DKI Jakarta Tahun 2017. Jurnal Mibar Demokrasi, 19(2), 12-27. https://doi.org/10.21009/jimd.v19i02.14528

Effendi, M. R. (2020). Mitigasi Intoleransi dan Radikalisme Beragama di Pondok Pesantren Melalui Pendekatan Pembelajaran Inklusif. Paedagogie| Jurnal Pendidikan dan Studi Islam, 1(1), 56-75.

Effendi, M. R., \& Syafrudin, I. (2020). Pertalian Agama Pada Pilkada DKI Jakarta Tahun 2017. Jurnal Ilmiah Mimbar Demokrasi, 19(02), 12-27.

Ghozali, Abdul Rahmat, 2003. Fiqih Munakahat, Jakarta : Kencana Prenada Media Group

Isteri-isteri yang bekerja Perum Citra Permata Sakinah, Wawancara Mendalam, Purwakarta September-Oktober 2019

J.,Winardi, 2008. Motivasi dan Pemotivasian, Jakarta : Raja Grafindo

Mila dan Endah, Isteri yang Bekerja Perum Citra Permata, Wawancara Mendalam, Purwakarta 22 September 2019

Moleong, Lexy J., , 2005. Metodelogi Penelitian Kualitatif, Bandung : Remaja Rosdakarya Mulia, Siti Musdah, 2011. Muslimah Sejati Menempuh Jalan Islami Meraih Ridha Ilahi, Bandung : Marja

Muthiah, Aulia, Hukum Islam Dinamika Seputar Hukum Keluarga, Yogyakarta : Pustaka Baru Press

N. Kesih, Panitera Muda Hukum PA Purwakarta, Wawancara Mendalam, Purwakarta, 3 Mei 2016

Nenek Ica, Mertua Ira (Isteri yang Bekerja Perum Citra Permata Sakinah) Wawancara Mendalam, Purwakarta 20 Oktober 2019

Robbins ,Stephen P., 1996. Perilaku Organisasi, Konsep, Kontroversi dan Aplikasi, Alih Bahasa : Hadyana Pujaatmaka, Edisi Keenam, Jakarta : Perlindo

Ruhiat, Praktisi Hukum di PA Purwakarta, Wawancara Mendalam, Purwakarta, 3 Mei 2016

Rusdiana, A., 2015. Manajemen Konflik, Bandung : CV. Pustaka Setia

Sastrapradja, M. 1981. Kamus Istilah Pendidikan dan Umum, Surabaya : Bina Ilmu

Simon, Fisher, dkk., 2001. Mengelola Konflik : Keterampilan dan Strategi untuk Bertindak, Jakarta : The British Council, Zen Books

Sugiyono, 2015. Metode Penelitian Pendidikan Pendekatan Kuantitatif, Kualitatif dan $R$ $\& D$, Bandung : Alfabeta

Tim Redaksi Fokusmedia, 2016. Undang-Undang Perkawinan (Edisi Lengkap), Bandung : Fokusmedia

Tim Redaksi Fokusmedia, t.th. Kompilasi Hukum Islam, Bandung : Fokusmedia

Yin, Robert K., 2015. Studi Kasus Desain dan Metode, Jakarta : Rajawali Press 